\title{
Fishery and Biology of Aristaeomorpha foliacea (Risso, 1827) (Crustacea: Decapoda) in the Northern Tyrrhenian Sea (Western Mediterranean)
}

\author{
P. Belcari and C. Viva \\ Dipartimento di Scienze dell'Uomo e dell'Ambiente \\ Università di Pisa, Via Volta 6, 56126 Pisa, Italy \\ M. Mori \\ Dipartimento Territorio e Risorse, Università di Genova, Genova, Italy \\ and \\ S. De Ranieri \\ Centro Interuniversitario di Biologia Marina ed Ecologia Applicata, Livorno, Italy
}

\begin{abstract}
The aim of the study was to provide information about the fishery, population size structure, breeding period and size at maturity of giant red shrimp, Aristaeomorpha foliacea, of the northern Tyrrhenian Sea, Italy. Data were collected directly at the local auction of Porto Santo Stefano, the main landing port of the study area, from 1991 to 1998 and during monthly surveys carried out during the year 1995. In Porto Santo Stefano the annual landing of red shrimps ranged between 2 and about 17 tons, corresponding to an annual average first sale income of 170-200 000 Euros. The fishery activity depended on season and vessel and the monthly landings per unit effort ranged from less than 1 to $35 \mathrm{~kg}$ /day/boat, although the catch of a single boat could reach values up to 80 $\mathrm{kg}$ /day. Size composition of $A$. foliacea ranged from 14 to $46 \mathrm{~mm}$ carapace length (CL) for males and from 14 to $66 \mathrm{~mm}$ CL for females. Recruitment occurred mainly in spring. The overall sexratio observed (1.10:1) was significantly biased towards females. Females begin to be mature in March, reaching a peak between July and August. From October to March most females had resting gonads. Mature males were found all year round. Females with spermatophores on the thelycum were found throughout the year, the highest percentages being recorded from March to September. The average size at sexual maturity was $40.59 \mathrm{~mm} \mathrm{CL}$. The average size of maximum reproductive potential was $37.15 \mathrm{~mm} \mathrm{CL}$.
\end{abstract}

Key words: Aristaeomorpha foliacea, Crustacea, Decapoda, Mediterranean, red shrimp fishery, reproductive biology, Tyrrhenian Sea

\section{Introduction}

One goal in studies on reproductive ecology of benthic crustaceans is to make and test generalizations about geographical variations in patterns of reproduction and recruitment. Such paradigms are useful for generating hypotheses about the specific environmental stimuli (proximate factors) and selective pressures (ultimate factors) that are responsible for breeding and recruitment patterns observed, as well as, for making predictions about possible changes in reproduction and recruitment due to natural fluctuations or anthropogenic alterations in these factors (Bauer and Rivera Vega, 1992). Further, knowledge of the dynamics of the reproductive process, which constitutes the basis of resource renewal, provides the suitable background for management direction (Crocos, 1987).

Because of its importance on the bathyal fishery grounds of the Mediterranean Sea, a number of papers have addressed the biology, ecology and fishery of the giant red shrimp Aristaeomopha foliacea (Risso, 1827). Most of the information relates to Italian waters of the central Mediterranean (Cau and Deiana, 1982; Cau et al., 1982; Ragonese, 1989; 1995, Mura et al., 1992; Bianchini and Ragonese, 1994; Ragonese et al., 1994, 1997; Matarrese et al., 1995; 
Ragonese and Bianchini, 1995; D’Onghia et al., 1998; Bianchini et al., 1998; Bianchini, 1999). Only scanty attention is devoted to the western basin (Lumare and Utzeri, 1973; Bianchini and Ragonese, 1994).

The northern Tyrrhenian Sea (western Mediterranean) is an important commercial fishery area for bathyal decapod crustaceans and $A$. foliacea is the most valuable deep-water resource (De Ranieri et al., 1994; De Ranieri, 1995; Ardizzone and Corsi, 1997; Biagi et al., 1998). Despite this, very little information is available on the life cycle of the species (Mori et al., 1994). The aim of present study was to provide information about the biology and fishery of $A$. foliacea inhabiting the northern Tyrrhenian Sea in order to carry out comparative regional studies and pinpoint differences.

\section{Materials and Methods}

The study was conducted at Porto Santo Stefano, Italy, the main landing point of the northern Tyrrhenian Sea, western Mediterranean. Landing data of $A$. foliacea from the bottom trawl fleet were recorded during three to five days per month at the local auction from 1991 to 1998 . Monthly total landings were estimated raising the sampled data to the total fishing days of the fleet in that month. The Landing Per Unit of Effort (LPUE) was calculated considering the fishing day as a unit of effort. Fishing effort data were calculated monthly by consulting the official archives. In the years 1995 to 1999 fishing activity was monitored, on a seasonal basis, by observations on board of commercial vessels fishing for Norway lobster and aristeid shrimps. In the sampled period, information from about 500 trawling hours was gathered. The collected data were analysed as hourly yields $(\mathrm{kg} / \mathrm{hr})$ and then studied on a seasonal basis.

Specimens of the giant red shrimp were collected by means of monthly sampling performed between January and December 1995 off the Tuscan Archipelago (northern Tyrrhenian Sea) at depths between 400 and $650 \mathrm{~m}$. The study area is shown in Fig. 1. Samples were collected by trawlers using a professional trawl net with mouth height of about $1 \mathrm{~m}$ and codend width of about $20 \mathrm{~m}$. Mesh size was about $40.0 \mathrm{~mm}$ stretched. During the months of February and December the sampling was not carried out because of bad weather.

For each specimen, the carapace length (CL) was measured, to the nearest $\mathrm{mm}$ below, from the right orbital margin to the mid posterior edge of the carapace. Males were distinguished from females by the presence of the petasma and assigned to two maturity stages, according to the scale proposed by Sardà and Demestre (1989) for the companion species Aristeus antennatus. The two stages, immature and mature, were based on the presence or absence of sperm sacs on the coxae of the fifth pair of pereiopods. Maturity stages for females were assigned according to the macroscopic colorimetric scale given by Levi and Vacchi (1988) and Kao et al. (1999), based on the different colours presented by the ovaries: fleshcolored, immature or spent, Stage I; light gray, maturing, Stage II; dark gray, early mature, Stage III; pale black, ripe, Stage IV. The presence of spermatophore was checked by visual examination of the thelycum.

Maturity condition and presence of spermatophores by size were estimated by fitting a logistic equation; in order to estimate the percentage of mature females in each size class, Stage III and Stage IV were combined. On the basis of two functional criteria (Morizur, 1983), maturity of gonads and presence of spermatophores, the size at the "maximum reproductive potential" was estimated. It was defined as the size corresponding to the intersection of the gonadic maturity curve and the mating complementary curve (i.e. absence of spermatophore) during the maximum reproductive activity of the stock (Ragonese and Bianchini 1995; D'Onghia et al., 1998).

Two moult stages were determined for both sexes, intermoult and postmoult, depending on the state of the exoskeleton: completely calcified in the former and at the beginning of calcification with a paperlike consistency in the latter. Significant deviations from the expected 1:1 sex ratio were tested using a $\chi^{2}$ test (Scossiroli and Palenzona, 1978).

\section{Results}

The observations on board of trawlers of Porto Santo Stefano allowed the identification of two fishing grounds for red shrimps located on bottoms from about 450 to $650 \mathrm{~m}$. The first is located westward of Pianosa and Montecristo Isles, the second between the Isles of Giglio and Montecristo (Fig. 1). Only a few boats operate in the area westward of Pianosa and Montecristo Isles. In the second area, the majority of trawlers of medium-large size (up to $700 \mathrm{~kW}$ engine power) from Porto Santo Stefano carry out their 


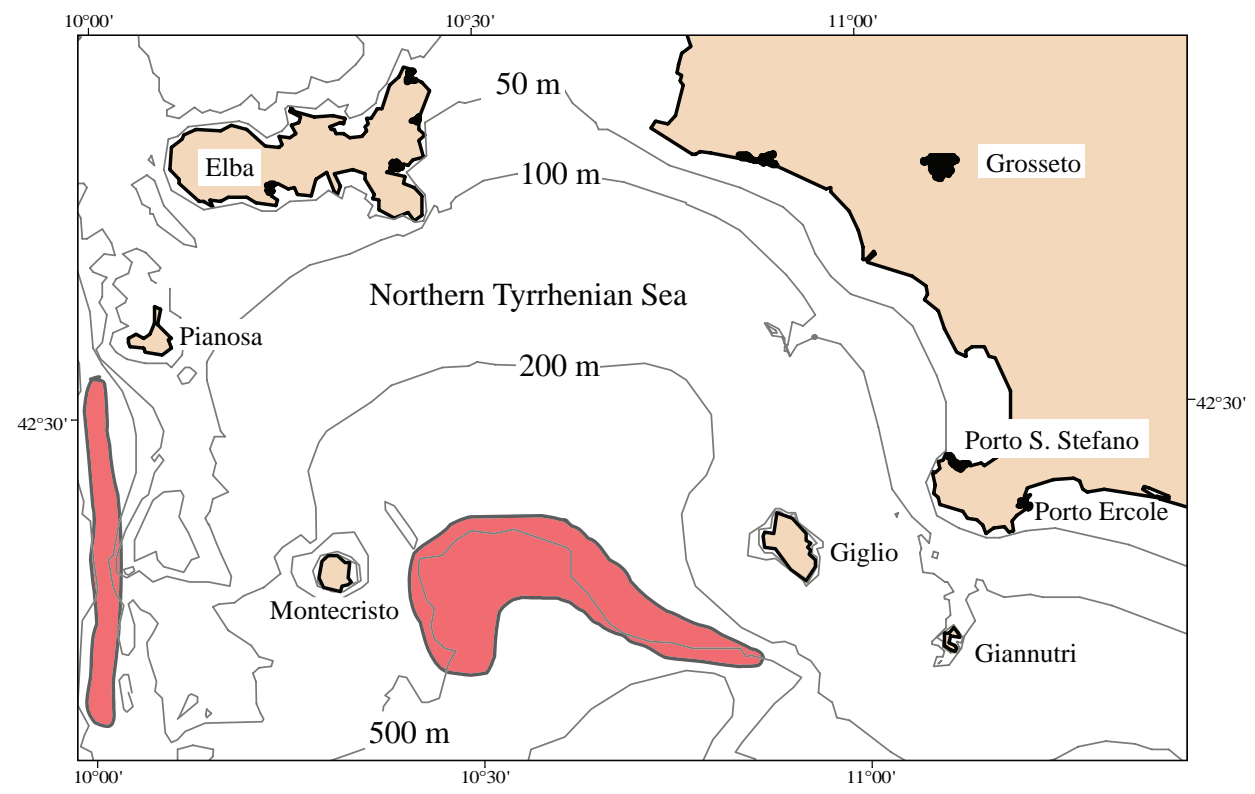

Fig. 1. Study area in the western Mediterranean.

fishing activity, devoted to red shrimps and Norway lobster, mostly during spring and summer. In both fishing grounds, A. foliacea was one of the target species, representing up to one third of the total commercial catch and was more important with respect to the companion species $A$. antennatus, ranging from $72 \%$ to $99 \%$ of the red shrimp average yield $(\mathrm{kg} / \mathrm{hr})$. The maximum yields observed were reached during the spring; due to the low fishing activity, data were not available for the winter season (Table 1).

In the period analysed, the annual landing in Porto Santo Stefano of red shrimps ranged between 2 and 17 tons, corresponding to an annual average first sale income of 170-200 000 Euros. Basically, the fishing activity depended on season and vessel; the monthly LPUE registered at the Porto Santo Stefano auction ranged from less than 1 to $35 \mathrm{~kg} /$ day/boat, although the catch of a single boat could reach values up to $80 \mathrm{~kg}$ /day (Fig. 2). Monthly average LPUE were characterised by a clear seasonality, with the highest values in late spring-summer.

During the monthly sampling at sea, a total of 5293 individuals of $A$. foliacea $(2780$ females and 2513 males) were collected in the investigated area. The maximum carapace lengths observed for males and females were $46 \mathrm{~mm}$ and $66 \mathrm{~mm}$, respectively, females attaining larger sizes than males (Fig. 3). The minimum size recovered was $14 \mathrm{~mm} \mathrm{CL}$. Small individuals with modal length around $20-22 \mathrm{~mm}$ CL were present during the spring months.
The overall sex-ratio observed (1.10:1) was significantly biased towards females $\left(\chi^{2}=13.5 ; P<0.005\right)$. The sex-ratio was near unity in the smallest size classes, but favoured males in intermediate classes and females in the largest classes. The monthly sex ratio showed a predominance of females from January to April, in September and November, while males predominated in August and October; from May to July the sex ratio did not differ significantly by $1: 1$ (Fig. 4).

\section{Reproductive biology}

Females of $A$. foliacea displayed seasonal sexual maturity (Fig. 5). Females started maturing in March and reached peak values between July and September. From October to March-April, most females were immature or had resting gonads (Stage I). The rare females caught in October with gonads at the Stage II probably reabsorbed their ovaries. The smallest mature female was observed in July at the size of $28 \mathrm{~mm}$ CL. Sexually mature males were always present, showing no evidence of a seasonal maturity cycle. The smallest mature male was registered at the size of $30 \mathrm{~mm} \mathrm{CL}$.

Females with spermatophores on the thelycum, indicating that mating had taken place, were observed throughout the year, although most of them were found from March to September (Fig. 6). The smallest females bearing spermatophores, measured $28 \mathrm{~mm} \mathrm{CL}$ and was found in September. 
TABLE 1. Seasonal mean yields per hour of red shrimps from 1995 to 1999 ; SE = standard error.

\begin{tabular}{|c|c|c|c|c|c|c|c|}
\hline & \multirow[t]{2}{*}{ Winter } & \multicolumn{2}{|c|}{ Spring } & \multicolumn{2}{|c|}{ Summer } & \multicolumn{2}{|c|}{ Autumn } \\
\hline & & Mean & $\mathrm{SE}$ & Mean & $\mathrm{SE}$ & Mean & $\mathrm{SE}$ \\
\hline A. foliacea & & 3.274 & 0.765 & 0.837 & 0.535 & 0.973 & 0.954 \\
\hline A. antennatus & & 0.505 & 0.061 & 0.324 & 0.301 & 0.053 & 0.051 \\
\hline
\end{tabular}



Fig. 2. Monthly LPUE of red shrimps A. foliacea and A. antennatus recorded at Porto S Stefano, the main landing point of the northern Tyrrhenian Sea.

The reproductive aspects by size were evaluated pooling data from April to September, the period of maximum reproductive activity. The size at which $50 \%$ of females were mature (Stage III and IV) was $40.59 \mathrm{~mm} \mathrm{CL}$, while $35.54 \mathrm{~mm}$ CL corresponded to the size at which $50 \%$ of females had spermatophores (Fig. 7 and 8). Large females without spermatophores were very few; they had probably lost them accidentally. The intersection of the logistic function for maturity and for absence of spermatophores gave the size of the "maximum reproductive potential" of 37.15 mm CL (Fig. 9).

\section{Moulting}

Moulting activity was performed all year long. Figure 10 shows the percentage of postmoulting males and females caught during the monthly samplings. In both sexes, catches of postmoulting individuals were high in spring and autumn, and very low in summertime. In males, moult took place mainly in May and September; in females, moult was greater in
March and November, before and after the reproductive season.

\section{Discussion}

In the northern Tyrrhenian Sea $A$. foliacea is one of the most valuable resources exploited by deep-sea fishery. Catches from fishing grounds at bottom depths greater than $450 \mathrm{~m}$ showed that this was an important target species. A. foliacea represented up to one third, as biomass, of the total commercial catch, corresponding to a high economic income (first sale price ranging from 20 to 30 Euros $/ \mathrm{kg}$ ). According to the national data series recorded by ISTAT (Italian Central Institute of Statistics), 43505 tons of red shrimps were landed in the period 1985-96 (ISTAT, 1988-99). This commercial category includes the two species A. foliacea and A. antennatus, making it impossible to assess individual catch levels. Our investigation and experimental trawl surveys conducted over the last fifteen years (Biagi et al., 1998) showed that in the area studied, $A$. foliacea was much more abundant 

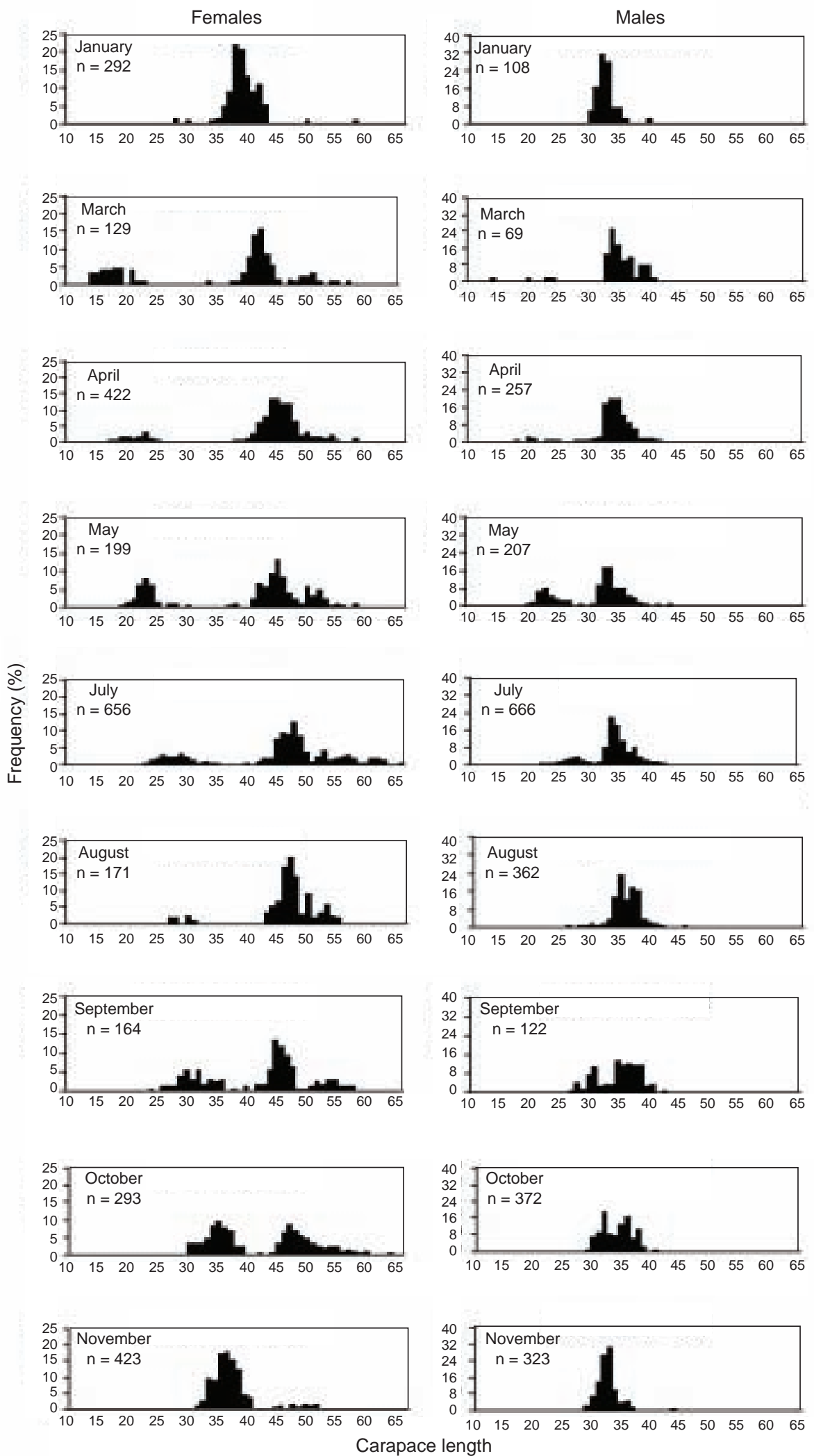

Fig. 3. Size frequency distributions of female and male A. foliacea collected during monthly samplings in the northern Tyrrhenian Sea. Samples that did not exceed 50 specimens were excluded. 
than the companion species $A$. antennatus, with percentages ranging from 72 to $99 \%$ of the total red shrimp catch.

In other areas of the western Mediterranean the opposite trend was observed. In the eastern basin, along the Mediterranean coast of Israel (ThessalouLegaki, 1994) and in Greek waters (Kapiris et al., 1999, 2001) a significantly higher abundance of A. foliacea has been reported recently, suggesting that the scanty presence registered previously was due to

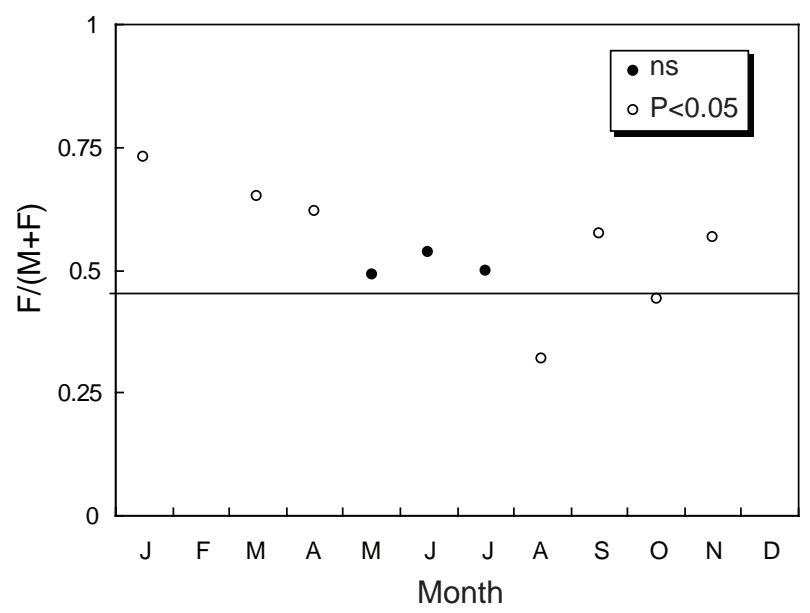

Fig. 4. Monthly sex ratio of $A$. foliacea from the northern Tyrrhenian Sea. lack of investigation at greater depths in this area. These recent data on the eastern side of the Mediterranean confirm the general assumption that the abundance of $A$. foliacea seems to follow longitudinal and latitudinal gradients (Campillo, 1994; D'Onghia et al., 1998). However, a patchy distribution is also observed. Thus the species is scarce or absent in the Catalan Sea, in the Gulf of Lions and in the Ligurian Sea (Sardà, 1986, Campillo, 1994; Orsi Relini and Relini, 1994), abundant in Tunisia (Ben Marien, 1994) and weakly present in Algeria (Yahiaoui, 1994), outnumbers $A$. antennatus in the northern Tyrrhenian Sea (Campillo, 1994; Biagi et al. 1998) and in the Sicilian channel (Ragonese and Bianchini, 1995), is present in almost equal proportions in the southeastern Tyrrhenian Sea (Greco et al., 1994) and again less abundant in the Ionian Sea (Pipitone and Andaloro, 1994; D'Onghia et al., 1998).

Long term observations of the catches revealed an abrupt decline in certain areas, such as the Gulf of Lions and the Ligurian Sea, followed by a sharp increase of A. antennatus (Relini and Orsi Relini, 1987; Campillo, 1994; Orsi Relini and Relini, 1994). Distribution and abundance of the giant red shrimp appear to be linked to the topography of the continental slope and submarine canyons and to trophic and hydrological factors. Although the species has been heavily exploited in the western Mediterranean, the wide fluctuations and decline do not appear to be related to an increase in fishing pressure. Instead, they have

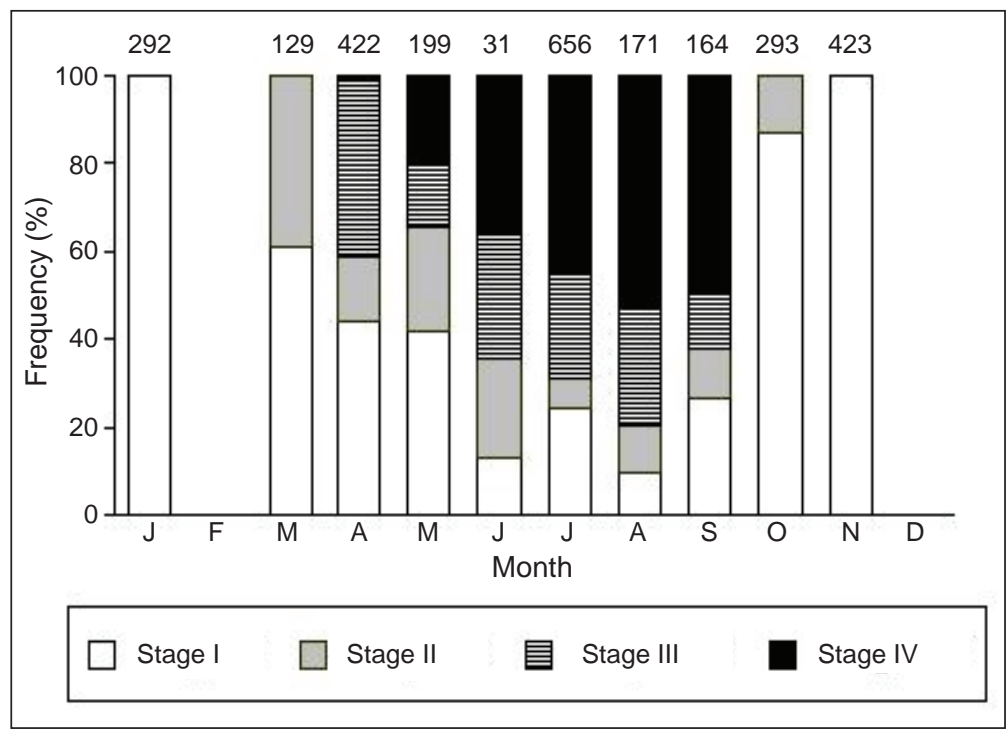

Fig. 5. Maturity stages of female A. foliacea from the northern Tyrrhenian Sea. Numbers above each histogram indicate the size of the sample. 


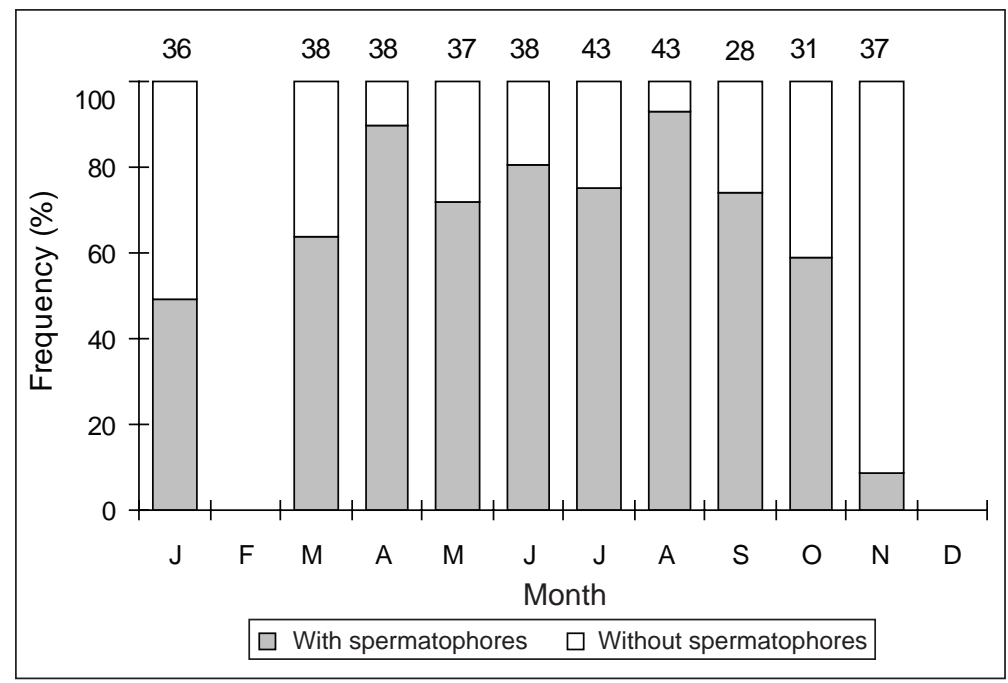

Fig. 6. Monthly percentage of female A. foliacea showing the presence or absence of spermatophores. For each month, the minimum size at which females bear spermatophores is indicated above the histograms.

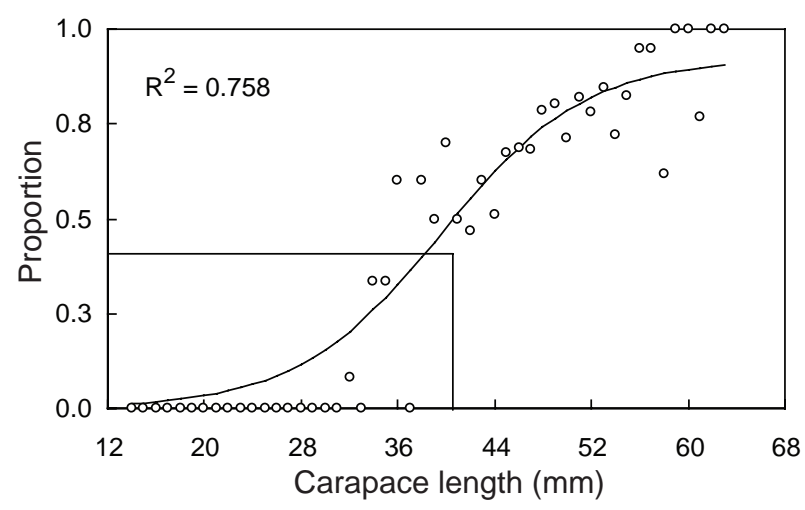

Fig. 7. Percentage by size of mature females (Stages III and IV).

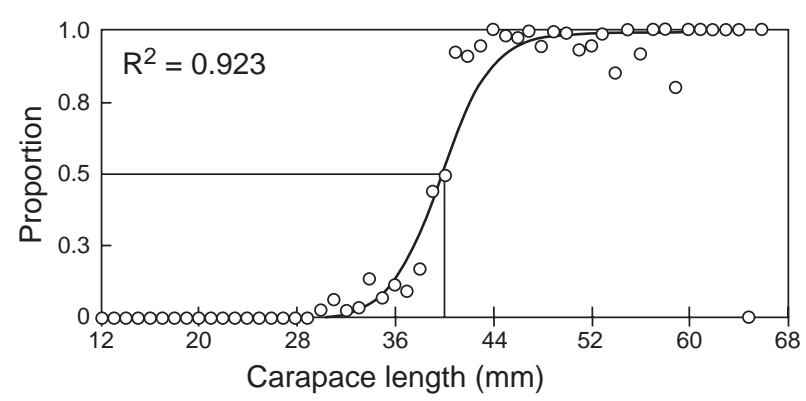

Fig. 8. Percentage by size of females with spermatophores. been attributed to a close correlation between the presence of the species and variations of hydrological factors. Changes in the water salinity rather than in temperature could explain its disappearance in certain regions of the Mediterranean, as in the Ligurian Sea, where the "Eastern or intermediate water" disappears after mixing with the superficial and deep waters (Murenu et al., 1994).

The marked seasonality of the landings observed in this study is likely to be related above all to the fact that adverse weather conditions during winter often prevent fishing vessels from operating at a distance from the coasts. Size frequency distributions exhibit a wide size range, with females attaining larger sizes than males. The distributions reflect those computed in the same area with specimens gathered by means of experimental trawl surveys based on stratified random samplings (Biagi et al., 1998). Percentage of large individuals is very low. During the spring months, an early component can be found, corresponding to the cohort of trawl net recruits, as already reported in the literature (Ragonese and Bianchini, 1995; D'Onghia et al., 1998; Spedicato et al., 1998).

Monthly variations in the sex ratio, slightly in favour of females or males according to season, indi- 


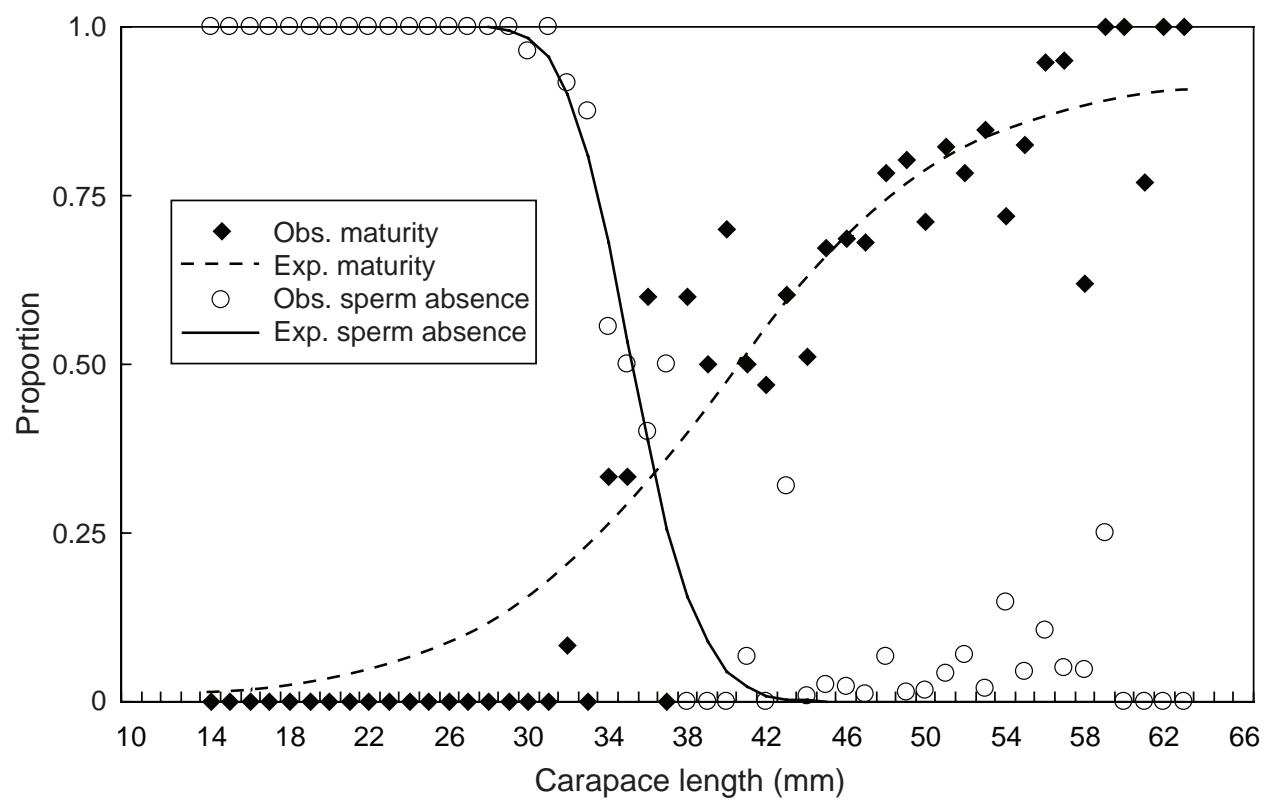

Fig. 9. Size at "maximum reproductive potential" for female $A$. foliacea caught in the northern Tyrrhenian Sea.

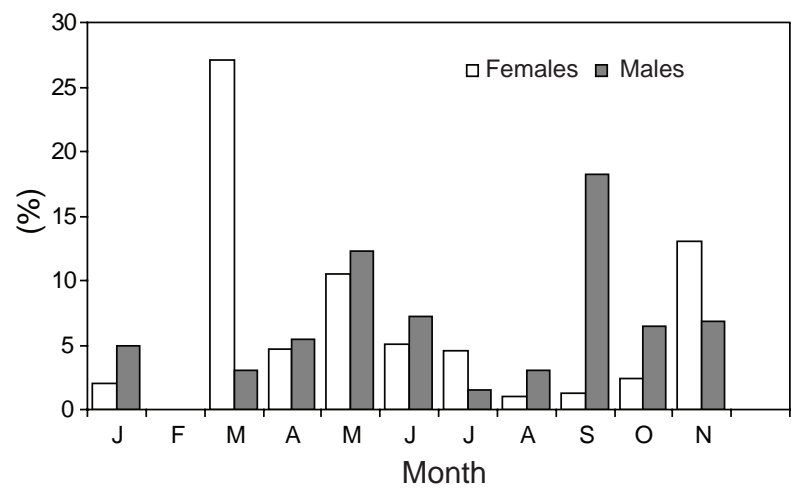

Fig.10. Postmoulting males and females of $A$. foliacea caught in the northern Tyrrhenian Sea.

cate very little segregation between sexes, although the overall sex ratio was biased toward females. The increase in number of males in late spring-summer is ascribed to their rising out of canyons or from the deepest areas for mating, as hypothesized by D'Onghia et al. (1998).

Data on reproductive activity are consistent with findings for the central Mediterranean (Cau and Deiana, 1982; Cau et al., 1982; Mura et al., 1992; Ragonese and Bianchini, 1995; D'Onghia et al., 1998). Females exhibit an extended reproductive period, from spring to autumn, with a peak between July and September. Mating activity is observed all year long, but the percentage of females bearing spermatophores is lower during autumn and winter. In the southeastern Mediterranean, the overall reproductive period is similar, but the peak is shifted one month earlier, in June (Kapiris and Thessalou-Legaki, 2001). Our findings on size at first maturity and at maximum reproductive potential are similar to those estimated for other areas (Ragonese and Bianchini, 1995; D’Onghia et al., 1998).

In the northern Tyrrhenian Sea, the exploitation of $A$. foliacea begins in the first juvenile stages or before reaching the maximum reproductive potential, as observed for other areas of the Mediterranean (Ragonese et al., 1997; D'Onghia et al., 1998; Spedicato et al., 1998; Bianchini, 1999). Studies previously carried out in the northern Tyrrhenian Sea on the exploitation state of $A$. foliacea indicated a condition close to the equilibrium (De Ranieri, 1999). These results and the recently observed reduction in this area of the trawl fleet exploiting this resource, indicate that no further modification of the current exploitation strategy is required.

\section{References}

ARDIZZONE, G. D. and F. CORSI (eds.). 1997. Atlante delle Risorse Ittiche Demersali Italiane. Biol. Mar. Medit., 4(2), $479 \mathrm{p}$. 
BAUER, R. T. and L. W. RIVERA VEGA. 1992. Pattern of reproduction and recruitment in two sicyonid shrimp species (Decapoda: Penaeidea) from a tropical seagrass habitat. J. Exp. Mar. Biol. Ecol., 161: 223-240.

BEN MARIEN, S. 1994. Aristaeomorpha foliacea and Aristeus antennatus in Tunisian waters. In: Life cycles and fisheries of the deep water red shrimps Aristaemorpha foliacea and Aristeus antennatus. M. L. Bianchini and S. Ragonese (eds.). Proceedings of the International Workshop held in the Istituto di Tecnologia della Pesca e del Pescato (ITPP-CNR), Mazara del Vallo, Italy. N.T.R. - I.T.P.P. Special Publications, No. 3, p. 50.

BIAGI, F., S. DE RANIERI, P. BELCARI, D. BERTOLINI, V. CHIERICONI, I. FARNOCCHIA, M. MORI, N. NANNINI, B. REALE, P. SARTOR, M. SBRANA, and C. VIVA. 1998. Valutazione delle risorse demersali nell'Arcipelago Toscano dall'Isola d'Elba all'Isola di Giannutri. Biol. Mar. Medit., 5(3): 40-52.

BIANCHINI, M. L. 1999. The Deep-Water Red Shrimp, Aristaeomorpha foliacea, of the Sicilian Channel: Biology and Exploitation. PhD Thesis, University of Washington, Seattle, WA, USA, 482 p.

BIANCHINI, M. L., L. DI STEFANO and S. RAGONESE. 1998. Trawl mesh selectivity and body engagement pattern in the red shrimp Aristaeomorpha foliacea (Risso, 1827) (Crustacea: Decapoda). J. Nat. Hist., 32(1011): 1431-1437.

BIANCHINI, M. L. and S. RAGONESE (eds.). 1994. Life cycles and fisheries of the deep water red shrimps Aristaemorpha foliacea and Aristeus antennatus. Proceedings of the International Workshop held in the Istituto di Tecnologia della Pesca e del Pescato (ITPPCNR), Mazara del Vallo, Italy. N.T.R. - I.T.P.P. Special Publications, No. 3: 88 p.

CAMPILLO, A. 1994. Bio-ecology of Aristeus antennatus in the French Mediterranean. In: Life cycles and fisheries of the deep water red shrimps Aristaemorpha foliacea and Aristeus antennatus. M. L. Bianchini and S. Ragonese (eds). Proceedings of the International Workshop held in the Istituto di Tecnologia della Pesca e del Pescato (ITPP-CNR), Mazara del Vallo, Italy. N.T.R. - I.T.P.P. Special Publications, No. 3: 25-26.

CAU, A. and A. M. DEIANA. 1982. Sulle variazioni di cattura del gambero rosso "Aristeomorpha foliacea" in relazione alla sua eco-etologia. Boll. Mus. Ist. Biol. Univ. Genova, 50(suppl): 145-150.

CAU, A., A. M. DEIANA and M. MURA. 1982. Nuovi dati sull'accrescimento e sulla maturità sessuale di Aristemorpha foliacea (Risso, 1827) (Decapoda Penaeidae). Naturalista Sicil., S. IV, VI (Suppl.), 2: 429434.

CROCOS, P. J. 1987. Reproductive Dynamics of the Grooved Tiger Prawn, Penaeus semisulcatus, in the North-western Gulf of Carpenteria, Australia. Austr. J. Mar. Freshw. Res., 38: 79-90.

DE RANIERI, S. 1995. Le risorse demersali nell'Arcipelago Toscano Meridionale. Atti Soc. Tosc. Sci. Nat. Mem., Serie A, CII: 185-195.

MS 1999. Valutazione delle risorse demersali dall'Isola d'Elba all'Isola di Giannutri. Final Report, MIPAF, $134 \mathrm{p}$.
DE RANIERI, S., P. BELCARI, D. BERTOLINI, F. BIAGI, M. MORI, B. REALE, P. SARTOR, M. SBRANA, and C. VIVA. 1994. Considerazioni sullo stato di sfruttamento delle risorse demersali (Isola d'Elba - Isola di Giannutri). Biol. Mar. Medit., 1(2): 27-39.

D'ONGHIA, G., P. MAIORANO, A. MATARRESE, and A. TURSI. 1998. Distribution, biology, and population dynamics of Aristaeomorpha foliacea (Risso, 1827) (Decapoda, Natantia, Aristeidae) in the north-western Ionian Sea (Mediterranean Sea). Crustaceana, 71(5): 518-544.

GRECO, S., F. PERDICHIZZI, B. SPALLETTA, D. CAPECCHI, and D. GIORDANO. 1994. Aristaeomorpha foliacea and Aristeus antennatus in south eastern Tyrrhenian Sea. In: Life cycles and fisheries of the deep water red shrimps Aristaemorpha foliacea and Aristeus antennatus. M. L. Bianchini and S. Ragonese (eds.), Proceedings of the International Workshop held in the Istituto di Tecnologia della Pesca e del Pescato (ITPP-CNR), Mazara del Vallo, Italy. N.T.R. - I.T.P.P. Special Publications, No. 3: 37-38.

KAO, H. C., T. Y. CHAN, and H. P. YU., 1999. Ovary development of the deep-water shrimp Aristaeomorpha foliacea (Risso, 1826) (Crustacea: Decapoda: Aristeidae) from Taiwan. Zool. Studies, 38: 373-378.

KAPIRIS K., M. THESSALOU-LEGAKI, G. PETRAKIS, M. MORAITOU-APOSTOLOPOULOU, and C. PAPACOSTANTINOU. 1999. Population characteristics and feeding parameters of Aristaemorpha foliacea and Aristeus antennatus (Decapoda: Aristeidae) from the Ionian Sea (Eastern Mediterranean). In: The Biodiversity Crisis and Crustacea. J. C. von Vaupel Klein and F. R. Schram (eds.), Crustacean Issue, 12: 177-191.

KAPIRIS K. and M. THESSALOU-LEGAKI. 2001. Observation on the reproduction of Aristaemorpha foliacea (Crustacea: Aristeidae) in the SE Ionian Sea. Rapp. Comm. Int. Mer Médit., 36: 281.

KAPIRIS, K., A. TURSI, C. MYTILINEOU, S. KAVADAS, D. D'ONGHIA, and M.T. SPEDICATO. 2001. Geographical and bathymetrical distribution of Aristaemorpha foliacea and Aristeus antennatus (Decapoda, Aristeidae) in the Greek Ionian Sea. Rapp. Comm.Int. Mer Médit., 36: 280.

ISTAT (Istituto Centrale di Statistica), 1988-1999. Statistiche della caccia e della pesca.

LEVI, D. and M. VACCHI. 1988. Macroscopic scale for simple and rapid determination of sexual maturity in Aristaemorpha foliacea (Risso, 1826) (Decapoda: Penaeidae). J.. Crust. Biol., 8(4): 532-538.

LUMARE, F. and C. UTZERI. 1973. Nota sulla pesca dei gamberi lungo le coste orientali della Corsica e nel Golfo dell'Asinara. Boll. Pesca. Piscic. Idrobiol., 28(1): 111119.

MATARRESE, A., G. D'ONGHIA, M. DEFLORIO, M. PANZA, and G. COSTANTINO. 1995. Recenti acquisizioni sulla distribuzione batimetrica di Aristaeomorpha foliacea e Aristeus antennatus (Crustacea, Decapoda) nel Mar Ionio. Biol. Mar. Medit., 2(2): 299-300.

MORI, M., F. BIAGI, and S. DE RANIERI. 1994. Reproductive biology of Aristaeomorpha foliacea in the 
Southern Tuscany archipelago (Central Tyrrhenian Sea). In: Life cycles and fisheries of the deep water red shrimps Aristaemorpha foliacea and Aristeus antennatus. M. L. Bianchini and S. Ragonese (eds.). Proceedings of the International Workshop held in the Istituto di Tecnologia della Pesca e del Pescato (ITPP-CNR), Mazara del Vallo, Italy. N.T.R. - I.T.P.P. Special Publications, No. 3: 31-32.

MORIZUR, Y. 1983. Utilisations des critères fonctionnels (présence de spermatophore, maturation des ovaires) pour la détermination de la taille et de l'âge à maturité sexuelle des Nephrops norvegicus femelles de la région sudBretagne. ICES J. Cons., 41: 28-36.

MURA, M., S. CAMPISI, and A. CAU. 1992. Osservazioni sulla biologia riproduttiva negli aristeidi demersali del Mediterraneo Centro-Occidentale. Oebalia, suppl. XVII: $75-80$.

MURENU, M., D. CUCCU, C. FOLLESA, A. SABATINI, and A. CAU. 1994. The occurence of Aristeomorpha foliacea in Sardinia waters. In: Life cycles and fisheries of the deep water red shrimps Aristaemorpha foliacea and Aristeus antennatus. M. L. Bianchini and S. Ragonese (eds.). Proceedings of the International Workshop held in the Istituto di Tecnologia della Pesca e del Pescato (ITPP-CNR), Mazara del Vallo, Italy. N.T.R. - I.T.P.P. Special Publications, No. 3, p. 49.

ORSI RELINI, L. and G. RELINI. 1994. Biological characteristics of Aristeus antennatus as highlighted by long-term observation in the Ligurian Sea. In: Life cycles and fisheries of the deep water red shrimps Aristaemorpha foliacea and Aristeus antennatus. M. L. Bianchini and S. Ragonese (eds.). Proceedings of the International Workshop held in the Istituto di Tecnologia della Pesca e del Pescato (ITPP-CNR), Mazara del Vallo, Italy. N.T.R. - I.T.P.P. Special Publications, No. 3: 2728.

PIPITONE, C. and F. ANDALORO. 1994. First observation of Aristaeomorpha foliacea and Aristeus antennatus along the Eastern Sicily coast. In: Life cycles and fisheries of the deep water red shrimps Aristaemorpha foliacea and Aristeus antennatus. M. L. Bianchini and S. Ragonese (eds.). Proceedings of the International Workshop held in the Istituto di Tecnologia della Pesca e del Pescato (ITPP-CNR), Mazara del Vallo, Italy. N.T.R. - I.T.P.P. Special Publications, No. 3, p. 59.

RAGONESE, S. 1989. Prima valutazione dello stock di Aristaemorpha foliacea Risso, 1827 (Crustacea, Aristeidae) del Canale di Sicilia. Nova Thalassia, 10(suppl. 1): 457-465.

RAGONESE, S. 1995. Geographical distribution of Aristaemorpha foliacea (Crustacea: Aristeidae) in the Sicilian Channel (Mediterranean Sea). ICES Mar. Sci. Symp., 199: 183-188.
RAGONESE, S., F. BERTOLINO, and M. L. BIANCHINI. 1997. Biometric relationships of the red shrimp, Aristaeomorpha foliacea Risso 1827, in the Strait of Sicily (Mediterranean Sea). Sci. Mar., 61(3): 367-377.

RAGONESE, S. and M. L. BIANCHINI. 1995. Size at sexual maturity in red shrimp females, Aristaeomorpha foliacea, from the Sicilian Channel (Mediterranean Sea). Crustaceana, 68(1): 73-82.

RAGONESE, S., M. L. BIANCHINI, L. DI STEFANO, S. CAMPAGNUOLO, and F. BERTOLINO. 1994. Aristaeomorpha foliacea in the Sicilian Channel. In: Life cycles and fisheries of the deep water red shrimps Aristaemorpha foliacea and Aristeus antennatus. M. L. Bianchini and S. Ragonese (eds.). Proceedings of the International Workshop held in the Istituto di Tecnologia della Pesca e del Pescato (ITPP-CNR), Mazara del Vallo, Italy. N.T.R. - I.T.P.P. Special Publications, No. 3: 45-46.

RELINI, G. and L. ORSI RELINI. 1987. The decline of red shrimps stocks in the Gulf of Genova. Inv. Pesq., 51 (suppl.1): 245-260.

SARDÀ, F. 1986. Data of Aristeus antennatus (Risso, 1816), distribution and abundance in the Western Mediterranean Sea. Some biological aspects. Rapp. Comm. Int. Mer Médit., 30(3): 118-120.

SARDA, F. and M. DEMESTRE. 1989. Shortening of the rostrum and rostral variability in Aristeus antennatus (Risso, 1816) (Decapoda: Aristeidae). J. Crust. Biol., 9(4): 570-577.

SCOSSIROLI, R. E., and D. L. PALENZONA., 1978. Manuale di Biometria. Zanichelli, Bologna, Italy. 259 p.

SPEDICATO, M. T., G. LEMBO, T. SILECCHIA, and P. CARBONARA. 1998. Contributo alla valutazione dello stato di sfruttamento del gambero rosso (Aristaeomorpha foliacea, Risso 1827) nel Tirreno Centro-Meridionale. Biol. Mar. Medit., 5(2): 252-261.

THESSALOU-LEGAKI, M. 1994. Distribution of Aristeus antennatus and Aristeomorpha foliacea in the Eastern Mediterranean Sea. In: Life cycles and fisheries of the deep water red shrimps Aristaemorpha foliacea and Aristeus antennatus. M. L. Bianchini and S. Ragonese (eds.). Proceedings of the International Workshop held in the Istituto di Tecnologia della Pesca e del Pescato (ITPP-CNR), Mazara del Vallo, Italy. N.T.R. - I.T.P.P. Special Publications, No. 3, p. 61.

YAHIAOUI, M. 1994. Distribution and reproduction cycle of Aristeus antennatus and Aristeomorpha foliacea in Algeria. In: Life cycles and fisheries of the deep water red shrimps Aristaemorpha foliacea and Aristeus antennatus. M. L. Bianchini and S. Ragonese (eds.). Proceedings of the International Workshop held in the Istituto di Tecnologia della Pesca e del Pescato (ITPP-CNR), Mazara del Vallo, Italy. N.T.R. - I.T.P.P. Special Publications, No. 3: 51-52. 